\title{
Influence of Foliar Applied Nitrogen on Reproductive Growth of Sunflower (Helianthus annuus L.) under Water Stress
}

\author{
Muhammad Haseeb1, Nazimah Maqbool2* \\ ${ }^{1}$ Department of Agronomy, University of Agriculture, Faisalabad, Pakistan \\ ${ }^{2}$ Department of Botany, University of Agriculture, Faisalabad, Pakistan \\ Email: "nazimahmaqbool@gmail.com
}

Received 10 November 2015; accepted 5 December 2015; published 10 December 2015

Copyright (C) 2015 by authors and Scientific Research Publishing Inc.

This work is licensed under the Creative Commons Attribution International License (CC BY). http://creativecommons.org/licenses/by/4.0/

c) (i) Open Access

\begin{abstract}
Nitrogen is a major nutrient involved in plant growth and yield. Plants cannot get the nutrients from the soil medium under water stress condition to testify foliar application in stress condition to fulfil plant need for better performance. In this regard, a field study was conducted to evaluate the effect of foliar-applied nitrogen (0, water and 1\% urea) on sunflower (cv. Hysun-33) under normal and water stress at reproductive stage. Two soil applied nitrogen levels control $\left(0 \mathrm{~kg} \cdot \mathrm{ha}^{-1}\right)$ and recommended dose (115 kg.ha-1). Supplemental foliar application of nitrogen in the form of urea significantly increased the growth, yield and yield components of sunflower under water stress. The increase in yield with $1 \%$ urea spray was recorded up to $1.37 \mathrm{t}^{-h^{-1}}$ in comparison to water spray $\left(1.07 \mathrm{t} \cdot \mathrm{ha}^{-1}\right)$ and no spray $\left(1.00 \mathrm{t} \cdot \mathrm{ha}^{-1}\right)$. While maximum values of all factors were obtained where $1 \%$ urea spray with soil applied nitrogen was used in both stresses as well as in nonstress condition. Therefore, reasonable yield can be achieved by applying foliar application of urea $(1 \%)$ as a supplemental source to soil applied nitrogen under water stress.
\end{abstract}

\section{Keywords}

Foliar Application, Urea, Water Stress, Sunflower, Yield

\section{Introduction}

Sunflower is one of the major oil producing crops grown worldwide. Globally, it ranks the fourth position and is grown on a large scale. In Pakistan, it has also emerged as an important oil seed crop due to its adaptability in

\footnotetext{
${ }^{*}$ Corresponding author.
}

How to cite this paper: Haseeb, M. and Maqbool, N. (2015) Influence of Foliar Applied Nitrogen on Reproductive Growth of Sunflower (Helianthus annuus L.) under Water Stress. Agricultural Sciences, 6, 1413-1420. 
soil and environmental condition [1]. The oil of sunflower is considered best as it has higher level of oleic acid which renders it more oxidative stability as compared to other oil seed crops such as safflower and canola having lower proportion of oleic acid. This unique feature makes it an essential antidote to deter coronary heart diseases [2].

Sunflower hybrid gave better yield when properly irrigated. Yield would increase if limited water was applied at specific growth stages [3]. Water stress affects the typical physiology, growth and yield of plants in different ways. It has been studied that worldwide reduction in sunflower production is associated with water stress [4]. Huge reduction in achene yield as well as biological yield of sunflower occurred with limited irrigation at flowering stage [5]. In drought affected soils the nutrient uptake is low because soil pores are occupied with air that obstructs water diffusion in roots, so nutrient uptake cannot be possible in such condition [6].

Nitrogen is one of the major essential elements of most of structural and functional components of plants [7]. It comprises $40 \%$ - $50 \%$ of dry matter of living protoplasm [8]. Nitrogen is involved in promoting crop production by improving partitioning and accumulation of dry matter in crop [9]. $\mathrm{N}$ fertilizer increases the chlorophyll contents by increasing the rubisco activity [10] and it is the essential component of increased weight and yield of chilies and tomatoes [11] [12]. Increase in the seed yield of sunflower is observed in different experiments by applying proper dose of nitrogen [13].

Under water stress, deficiency of nitrogen reduced the plant growth [14]. To fulfill this deficiency of nutrients especially nitrogen under water deficit, supplemental foliar spray may be the best option instead of soil application. Damage of water stress can be limited by providing nitrogen properly [13]. Foliar application can supplement the deficiency of nutrients under water stress conditions as it is an advantage in field conditions where the uptake of nutrients is restricted by variety of abiotic and biotic stresses. Foliar application is another option when nutrient deficiencies cannot be corrected by soil application of nutrients [15].

The main aim of this study was to find the efficiency of foliar applied nitrogen in fulfilling the demand of nitrogen at reproductive stage by alleviating the effect.

\section{Material and Methods}

\subsection{Field Preparation}

An experiment was conducted at crop physiology research area, University of Agriculture, Faisalabad, to study the effect of supplemental foliar nitrogen application on sunflower var. Hysun-33 under water stress at reproductive stage. The crop was sown on 10th of August, 2013 by using ridge sowing method, keeping row to row distance of $70 \mathrm{~cm}$ and plant to plant distance of $22 \mathrm{~cm}$ using a seed rate $8 \mathrm{~kg} \cdot \mathrm{ha}^{-1}$. Potassium (K) and phosphorus (P) was applied at the time of sowing. Nitrogen was applied in the form of three split doses and foliar application was done just before reproductive stage.

\subsection{Treatment}

The experiment consisted of treatments i.e. Stress Level as Main Plot Factor including Control and Water Stress at Reproductive Stage; subpllots comprised of Soil applied nitrogen including $0 \mathrm{~kg} \cdot \mathrm{ha}^{-1}$ and $\mathrm{N}_{1} 150 \mathrm{~kg} \cdot \mathrm{ha}{ }^{-1}$; Spray at reproductive stage including, Unspray, Water Spray and 1\% urea spray.

\subsection{Measurement}

Plants from three replicates were used to measure head diameter (cm), number of achenes per head, 1000 achenes weight $(\mathrm{g})$, achene yield $\left(\mathrm{t} \cdot \mathrm{ha}^{-1}\right)$, biological yield $\left(\mathrm{t} \cdot \mathrm{ha} \mathrm{H}^{-1}\right)$ and harvest index $(\%)$. Chlorophyll content (mg/ml) was estimated by the Arnon method. Osmotic potential (MPa) was measured by Osmometer (Wescor, 5520) using a drop of crushed leaf sample in an Eppendorf tube, Leaf water potential (MPa) was gauged by Scholander type pressure chamber (Arimad-2, Japan).

\subsection{Statistical Analysis}

The experiment was arranged in three factor factorial split-split plot design with three replications. Data was analyzed using Statistix 8.1 and means were compared by Duncan's Multiple Range Test (DMRT) at 5\% level of confidence. 


\section{Results}

Chlorophyll contents are the most important physiological parameter which decides the photosynthetic rate. It accumulation contributes to final yield by enhancing the achene weight (Figure 1(a), Figure 1(b)). Maximum chlorophyll $\mathrm{a}$ and $\mathrm{b}$ were observed in plots receiving no stress with soil applied nitrogen and $1 \%$ urea spray. While minimum values were observed in plants having water stress with no soil nitrogen and no foliar spray. Water stress significantly decreased the chl a and b. Soil applied nitrogen under no stress gave maximum value while minimum value was recorded where no soil applied N under water stress condition. Similarly, foliar spray of urea had significantly increased the chlorophyll value.

Maximum osmotic potential (1.48 MPa) was observed in plots having no water stress with no soil applied N and $1 \%$ urea spray. While minimum water potential (1.97 $\mathrm{MPa}$ ) was recorded in plots receiving water stress with no soil applied $\mathrm{N}$ and no foliar spray. Water stress significantly decreased the osmotic potential value (Figure 1(c)).

Maximum water potential (0.66) was observed in plots containing no water stress with no soil application of nitrogen with water spray while minimum water potential (1.15) was recorded in plots receiving water stress with soil applied nitrogen and 1\% urea spray. Water stress significantly decreased the water potential value. Similarly, foliar spray of water had significantly increased the water potential while both other levels of foliar spray were at statistically at power with each other (Figure 1(d)).

Head diameter (Figure 2(a)) significantly affected by the 1\% urea spray as it gave maximum head diameter of $(19.20 \mathrm{~cm})$ under normal condition with urea spray followed by water spray and no spray. While minimum head diameter measured in plots having water stress with no soil applied nitrogen under no foliar spray. Water stress has significantly decreased the head diameter.

Achene weight is an important parameter for determining the yield. It gives an idea of photosynthetic accumulation in achene and shows the importance of water for the food translocation.

Maximum achene weight was obtained in plots receiving no stress with soil applied nitrogen and $1 \%$ urea spray. While minimum value shown by plots having water stress with no soil applied nitrogen and no foliar spray. Water stress significantly decreased the 1000-achene weight. Similarly foliar spray significantly increased the 1000-achene weight followed by water spray (Figure 2(b)).

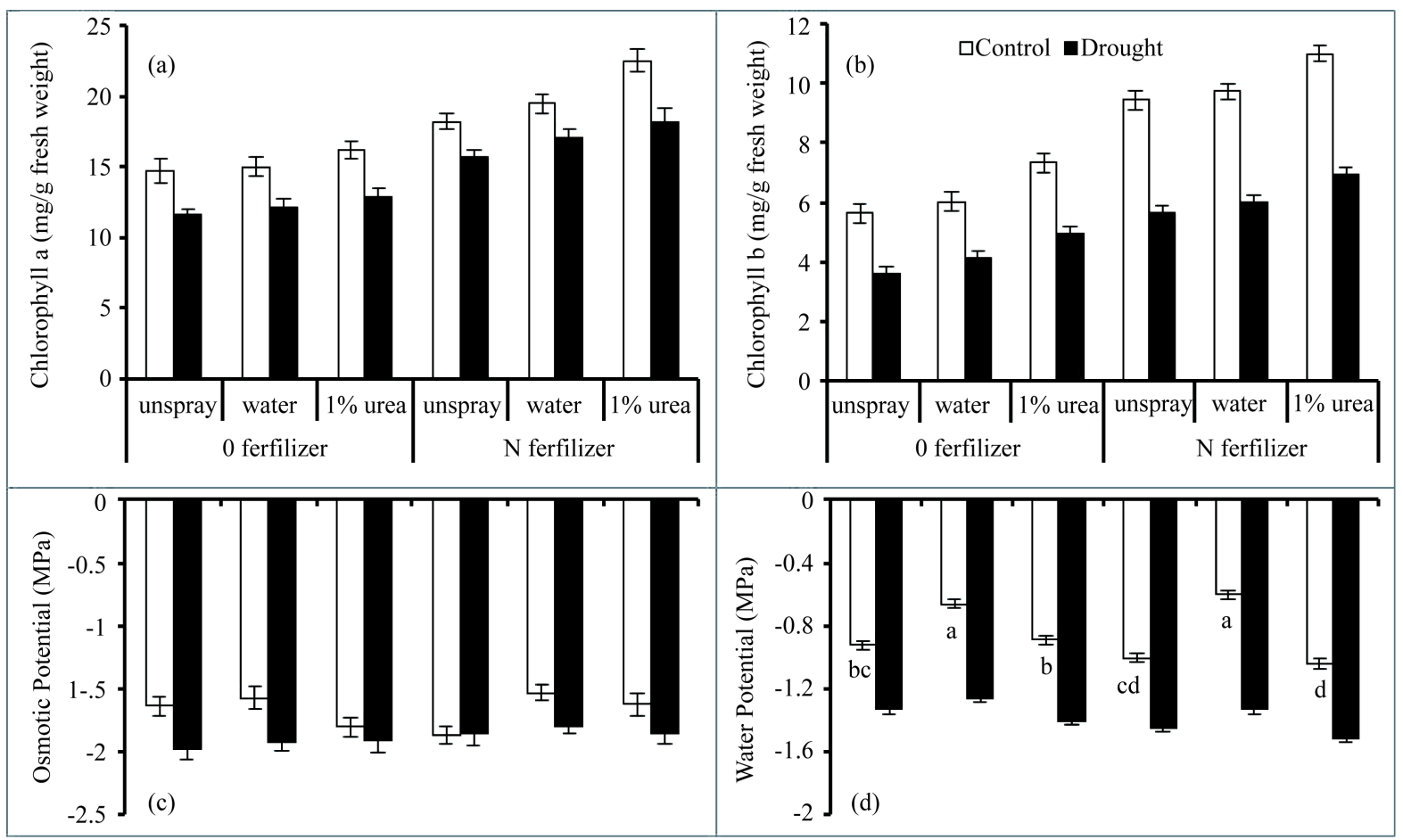

Figure 1. Chlorophyll a (a) and chlorophyll b (b), osmotic potential (MPa) (c), water potential (MPa) (d) of sunflower (Helianthus annuus L.) grown under water stress along with foliar applied nitrogen. 


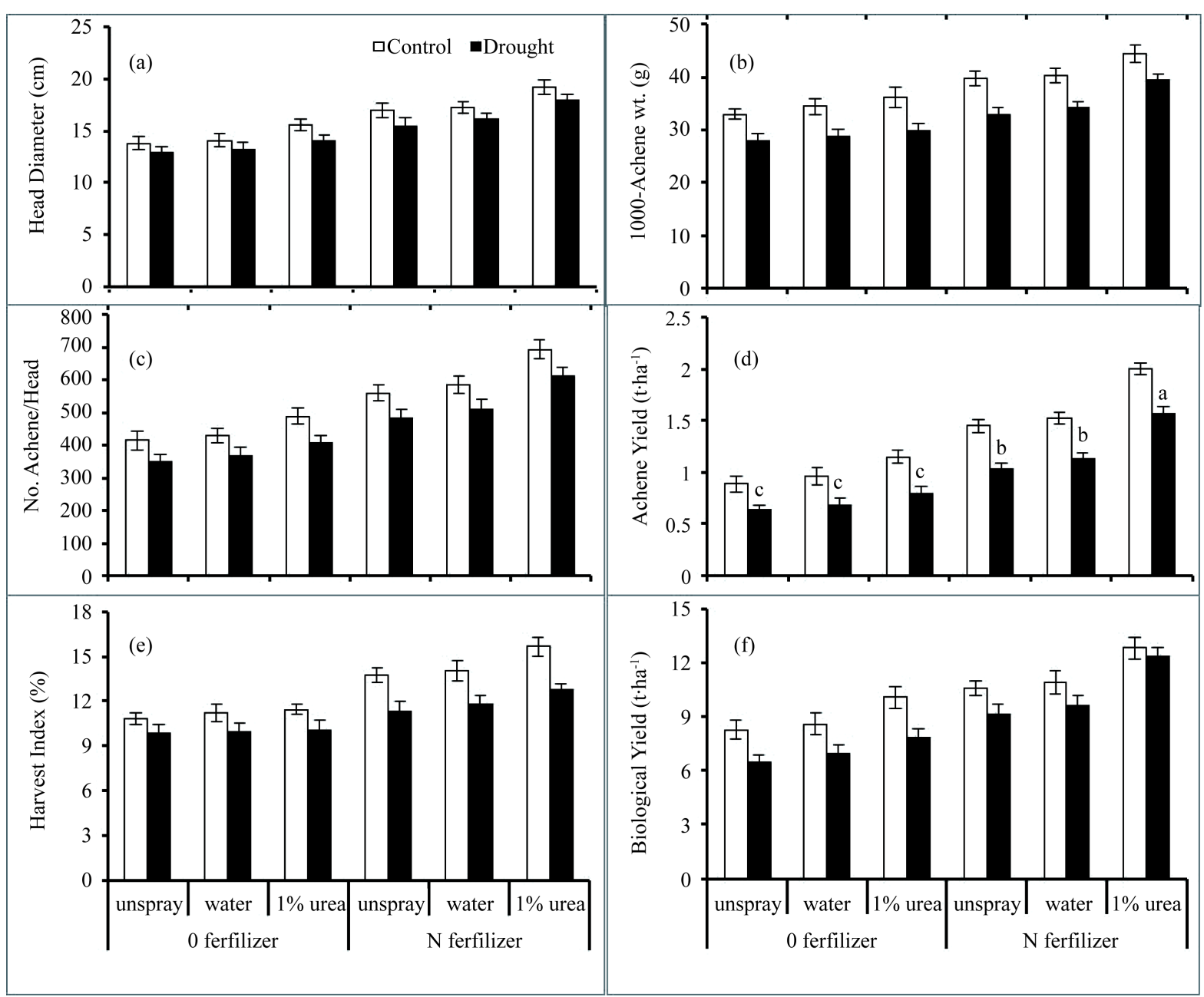

Figure 2. Head diameter (a), 1000-achenes weight (b), number of Achenes per head (c), achene yield (d), harvest index (e) and biological yield (f) of sunflower (Helianthus annuus L.) grown under water stress along with foliar applied nitrogen.

Maximum numbers of achene (Figure 2(c)) were obtained in plots treatment receiving no stress with soil applied nitrogen and $1 \%$ urea spray. While minimum number shown by plots having water stress with no soil applied nitrogen and no foliar spray. Water stress significantly decreased the numbers of achene. However, soil applied nitrogen under non water stress gave maximum numbers of achene while minimum value was observed where no soil applied nitrogen under water stress condition. Similarly foliar spray of urea has significantly increased the numbers of achene followed by water spray.

Individual comparison of treatment means (Figure 2(d)) indicated maximum achene yield was obtained in plots receiving by no stress with soil applied nitrogen and $1 \%$ urea spray. While minimum achene yield was obtained in plots having water stress with no soil applied nitrogen and no foliar spray. Water stress significantly decreased the achene yield. While soil applied nitrogen under no stress gave maximum yield but minimum value was observed where no soil applied nitrogen under water stress condition. Foliar application of urea has also significantly increased the achene yield followed by water spray.

Harvest index (Figure 2(e)) shows the percentage of how much economic yield produced from the biomass, maximum harvest index (15.64) was observed in plots where there was no water stress with soil applied nitrogen and $1 \%$ urea spray and minimum value (9.87) was observed in plots where there was water stress with no soil applied $\mathrm{N}$ and no foliar spray. Water stress significantly reduced the harvest index. Whereas soil applied nitrogen under no stress significantly increased the harvest index while minimum value was observed in no soil applied nitrogen under water stress treatment. Similarly foliar application of urea has significantly increased the harvest index followed by water spray. 
The experiment results revealed that maximum biological yield (Figure 2(f)) was achieved in plots receiving no stress with soil applied nitrogen and $1 \%$ foliar spray while minimum biological yield obtained in plots having water stress with no soil applied nitrogen and no foliar spray. Water stress significantly reduced the biological yield. Soil applied $\mathrm{N}$ under no stress gave maximum value and minimum value was observed in case of no soil application under water stress condition. Similarly foliar spray significantly maximize the biological yield followed by water stress under both water and non-stress conditions. Statistical significance of all the studied attributes was tabulated in Table 1.

\section{Discussion}

Nitrogen is one of the major components of photosynthetic machinery (chloroplast) in plants and mobilization of organic nitrogen controls the uptake and partitioning of carbon from leaf to seed sinks [16]-[18]. Water stress induces growth and yield loss of a crop due to reduce nutrient uptake, transport and distribution [19]. Water stress at any stage of plant growth adversely affects the yield of a plant but seed setting stage is the critical one [20]. The nitrogen supplement compensates the yield loss of wheat and deteriorative effect of water deficit conditions [21]. The deficiency of plant nitrogen under water stress at vegetative stage can be indemnified by the foliar application of urea as its effectiveness amplifies the nitrogen use efficiency of plant [22] by facilitating the timely translocation of nitrogen through leaf tissues. The urease enzyme hydrolyses urea giving ammonia as a

Table 1. ANOVA of reproductive stage parameters of water stressed sunflower hybrid treated with foliar applied urea (splitsplit plots).

\begin{tabular}{|c|c|c|c|c|c|c|}
\hline & df & Chlorophyll a & Chlorophyll b & Osmotic potential & Water potential & Head diameter \\
\hline Water Stress (S) & 1 & $86.11^{*}$ & $82.14 * *$ & $0.42 *$ & $2.58^{* *}$ & $13.81 \mathrm{~ns}$ \\
\hline N Fertilizer (N) & 1 & $204.2 * * *$ & $75.34^{* * *}$ & $0.01 \mathrm{~ns}$ & $0.06 * * *$ & $93.76^{* * *}$ \\
\hline Foliar Spray (F) & 2 & $35.18^{* * *}$ & $13.18^{* * *}$ & $0.1 \mathrm{~ns}$ & $0.42 * * *$ & $23.47 * *$ \\
\hline $\mathrm{N} \times \mathrm{S}$ & 1 & $0.0005 \mathrm{~ns}$ & $7.99 * * *$ & $0.02 \mathrm{~ns}$ & $0.002 \mathrm{~ns}$ & $0.08 \mathrm{~ns}$ \\
\hline $\mathrm{F} \times \mathrm{S}$ & 2 & $2.54 \mathrm{~ns}$ & $0.21 \mathrm{~ns}$ & $0.03 \mathrm{~ns}$ & $0.08^{* * *}$ & $0.24 \mathrm{~ns}$ \\
\hline $\mathrm{F} \times \mathrm{N}$ & 2 & $5.79 \mathrm{~ns}$ & $0.06 \mathrm{~ns}$ & $0.04 \mathrm{~ns}$ & $0.03^{*}$ & $1.26 \mathrm{~ns}$ \\
\hline $\mathrm{F} \times \mathrm{N} \times \mathrm{S}$ & 2 & $1.3 \mathrm{~ns}$ & $0.02 \mathrm{~ns}$ & $0.07 \mathrm{~ns}$ & $0.01 \mathrm{~ns}$ & $0.29 \mathrm{~ns}$ \\
\hline Main Plot Error & 2 & 6.34 & 0.28 & 0.01 & 0.006 & 2.46 \\
\hline Subplot Error & 4 & 8.13 & 0.36 & 0.08 & 0.002 & 1.79 \\
\hline \multirow[t]{2}{*}{ Error } & 16 & 15.45 & 4.51 & 0.30 & 0.04 & 21.08 \\
\hline & & 1000-Achenes weight & No. of achenes per head & Achene yield & Biological yield & Harvest index \\
\hline Water Stress (S) & 1 & $307.82 * *$ & $49284^{*}$ & $1.18^{*}$ & $18.59 * *$ & $30.5^{*}$ \\
\hline N Fertilizer (N) & 1 & $421.13^{* *}$ & $242392 * * *$ & $3.19 * * *$ & $71.84 * *$ & $63.36 * * *$ \\
\hline Foliar Spray (F) & 2 & $106.21^{* *}$ & $63405^{* * *}$ & $0.93^{* * *}$ & $33.4 * * *$ & $7.39 * *$ \\
\hline $\mathrm{N} \times \mathrm{S}$ & 1 & $0.11 \mathrm{~ns}$ & $144 \mathrm{~ns}$ & $0.02 \mathrm{~ns}$ & $1.93 \mathrm{~ns}$ & $3.69 \mathrm{~ns}$ \\
\hline $\mathrm{F} \times \mathrm{S}$ & 2 & $0.07 \mathrm{~ns}$ & $351.16 \mathrm{~ns}$ & $0.006 \mathrm{~ns}$ & $0.01 \mathrm{~ns}$ & $0.34 \mathrm{~ns}$ \\
\hline $\mathrm{F} \times \mathrm{N}$ & 2 & 20.25 ns & 8085.05 ns & $0.22^{* *}$ & $2.99 \mathrm{~ns}$ & $2.9 \mathrm{~ns}$ \\
\hline $\mathrm{F} \times \mathrm{N} \times \mathrm{S}$ & 2 & $3.33 \mathrm{~ns}$ & $211.16 \mathrm{~ns}$ & $0.003 \mathrm{~ns}$ & $0.71 \mathrm{~ns}$ & 0.14 ns \\
\hline Main Plot Error & 2 & 2.38 & 2602.66 & 0.04 & 0.28 & 1.41 \\
\hline Subplot Error & 4 & 33.43 & 2367.55 & 0.03 & 6.86 & 2.84 \\
\hline Error & 16 & 107.32 & 34733.55 & 0.194 & 12.91 & 8.15 \\
\hline
\end{tabular}

*** highly significant; **, * significant; ns: non-significant. 
product in leaves for C partitioning in seeds [23] [24]. The results of this study showed that the foliar application of nitrogen was beneficial to sunflower growth, development and yield. Chlorophyll a and b both show decreasing trend under water stress condition. Reasonable Chlorophyll contents increased under the $1 \%$ urea spray in water stress as compared to no stress condition. It is due to the fact that sunflower $50 \%$ nitrogen is associated with photosynthetic enzyme rubisco [25]. Consequently, lower rates of photosynthesis under conditions of nitrogen limitation are often attributed to decrease in chlorophyll contents and rubisco activity. Maximum water potential $(-0.66)$ was recorded under treatment where no water stress under water spray as compared to minimum $(-1.51)$ value where water stress with $1 \%$ urea spray was applied. As foliar spray of urea and no spray values are at power so these are significantly not differ from each other but differ from the water spray. The time and duration of foliar application determine the fate of plant yield [26]. In this experiment, as all yield related parameters were influenced by $1 \%$ urea spray. Head diameter was increased under water stress when urea spray is applied at reproductive stage, as compared to other treatments where no foliar spray was applied under water stress. Plants with greater head diameter leads to increased number of achenes and finally leads to maximum achene yield in comparison to no foliar spray [27] [28]. Without foliar spray, the deficiency of nitrogen decrease the achene yield of water stressed sunflower plants as in wheat [20]. Ability of plants to survive under water stress depends upon the roots ability to extract nitrogen from the environment. Under water deficient condition, plants stomata are closed which decreased the transpiration stream resultant in reduction of nutrients especially nitrogen. It is due to the fact that foliar applied nitrogen is absorbed by plants more rapidly than other methods. Nitrogen is important part of different structural and metabolic compounds in plants [29]. Nitrogen contributes $80 \%$ out of total nutrients absorbed by plants. Besides, an increased supply of photosynthates to head would also provide an opportunity for seeds to grow to their full potential, with an obvious increase in 1000-achenes weight [30]. The improvement in yield attributes after foliar application of $\mathrm{N}$ led to higher biological and achenes yield. The crop to produce an economic yield depends not only on the size of photosynthetic system, its efficiency, and translocation of dry matter into seed yield [31]. Hence, harvest index (HI) is an important trait in determining economic yield and represents an increased physiological capacity (sink power) to mobilize photosynthates and translocate them to organs of economic value [32]. It can, therefore, be inferred from the higher HI that the crop had a higher capacity to translocate photosynthates towards economic sinks when soil nitrogen with foliar urea spray were applied together, resulting in higher seed yield.

\section{Conclusion}

The foliar application of urea and its integration with recommended dose of soil applied nitrogen fertilizer improved the yield of water stressed sunflower (Helianthus annuus L.), especially when sprayed at reproductive stage. This dose of urea is recommended for nitrogen as well as water deficit soils for the better yield of a crop. The future work will be to testify the efficiency of this foliar applied urea level on other crops under different abiotic stresses.

\section{References}

[1] Javed, M.S., Ali, A. and Badar, H. (2003) Factors Affecting the Yield of Sunflower in Punjab. Pakistan Journal of Social Sciences, 1, 42-44.

[2] Allman-Farinelli, M.A., Gomes, K., Favaloro, E.J. and Petocz, P. (2005) A Diet Rich in High-Oleic-Acid Sunflower Oil Favourably Alters Low-Density Lipoprotein Cholesterol, Triglycerides, and Factor VII Coagulant Activity. Journal of American Dietary Association, 105, 1071-1079. http://dx.doi.org/10.1016/j.jada.2005.04.008

[3] Alahdadi, I., Oraki, H. and Khajani, F.P. (2011) Effect of Water Stress on Yield and Yield Components of Sunflower Hybrids. African Journal of Biotechnology, 10, 6504-6509.

[4] Mobasser, H.R. and Tavassoli, A. (2013) Effect of Water Stress on Quantitative and Qualitative Characteristics of Yield in Sunflower (Heliantus annuus L.). Journal of Novel Applied Sciences, 2, 299-302.

[5] Demir, A.O., Goksoy, A.T., Buyukcangaz, H., Turan, Z.M. and Koksal, E.S. (2006) Deficit Irrigation of Sunflower (Helianthus annuus L.) in a Humid Climate. Irrigation Science, 24, 279-289. http://dx.doi.org/10.1007/s00271-006-0028-x

[6] Ghanbari, A., Siahsar, B. Tavassoli, A., Esmaeilian, Y. and Babaeian, M. (2011) Effects of Uniconazole and Cycoel on Growth, Yield and Nutrients Uptake of Pearl Millet under Drought Stress Condition. American-Eurasian Journal of Agricultural and Environmental Sciences, 10, 857-862. 
[7] Ohyama, T. (2010) Nitrogen as a Major Essential Element of Plants. In: Ohyama, T. and Sueyoshi, K., Eds., Nitrogen Assimilation in Plants, Research Singpot, Kerala, 1-18.

[8] Togun, A.O., Akanbi, W.B. and Dris, R. (2003) Influence of Compost and Nitrogen Fertilizer on Growth, Nutrient Uptake and Fruit Yield of Tomato (Lycopersicum esculentum). Journal of Crop Research, 98, 40-56.

[9] Papantoniou, A.N., Tsialtas, J.T. and Papakosta, D.K. (2012) Dry Matter and Nitrogen Partitioning and Translocation in Winter Oilseed Rape (Brassica napus L.) Grown under Rainfed Mediterranean Conditions. Crop Pasture Science, 64, 115-122. http://dx.doi.org/10.1071/CP12401

[10] Pankovic, D., Plesnicar, M., Arsenijevic-Maksimovic, I., Petrovic, N., Sakac, Z. and Kastori, R. (2000) Effect of Nitrogen Nutrition on Photosynthesis in Cd-Treated Sunflower Plants. Annals of Botany, 86, 841-847. http://dx.doi.org/10.1006/anbo.2000.1250

[11] Tumbare, A.D. and Niikam, D.R. (2004) Effect of Planting and Fertigation on Growth and Yield of Green Chili (Capsicum annuum). Indian Journal of Agriculture and Science, 74, 242-245.

[12] Aminifard, M.H., Aroiee, H., Nemati, H., Azizi, M. and Khayyat, M. (2015) Effect of Nitrogen Fertilizer on Vegetative and Rreproductive Growth of Pepper Plants under Field Conditions. Journal of Plant Nutrition, 35, $235-242$. http://dx.doi.org/10.1080/01904167.2012.636126

[13] Waraich, E.A., Amad, R., Saifullah, M.Y.A. and Ahmad, M. (2011) Improving Agricultural Water Use Efficiency by Nutrient Management. Acta Agriculturae Scandinavica Soil Plant Science, 61, 291-304.

[14] Da Silva, E.C., Nogueira, J.M.C., da Silva, M.A. and de Albuquerque, M.B. (2011) Drought Stress and Plant Nutrition. Plant Stress, 1, 32-41.

[15] Cakmak, I. (2008) Enrichment of Cereal Grains with Zinc: Agronomic or Genetic Biofortification. Plant and Soil, 302, 1-17. http://dx.doi.org/10.1007/s11104-007-9466-3

[16] Thornton, B., Paterson, E., Kingston-Smith, A.H., Pratt, S. and Sim, A. (2002) Reduced Atmospheric $\mathrm{CO}_{2}$ Inhibits Nitrogen Mobilization in Festuca rubra. Physiologia Plantarum, 116, 62-72. http://dx.doi.org/10.1034/j.1399-3054.2002.1160108.x

[17] Barbottin, A., Bouchard, C. and Jeuffroy, M. (2005) Nitrogen Remobilization during Grain Filling in Wheat: Genotypic and Environmental Effect. Crop Science, 45, 1141-1150. http://dx.doi.org/10.2135/cropsci2003.0361

[18] Lillo, C. (2008) Signalling Cascades Integrating Light Enhanced Nitrate Metabolism. Biochemistry Journal, 414, 11-19. http://dx.doi.org/10.1042/BJ20081115

[19] Rouphael, Y., Cardarelli, M., Schwarz, D., Franken, P. and Colla, G. (2012) Effect of Drought on Nutrient Uptake and Assimilation in Vegetable Crops. In: Aroca, R., Ed., Plant Responses to Drought Stress, Springer, Berlin Heidelberg, 171-195. http://dx.doi.org/10.1007/978-3-642-32653-0_7

[20] Abdoli, M. and Saeidi, M. (2012) Effect of Water Deficiency Stress during Seed Growth on Yield and Its Components, Germination and Seedling Growth Parameters of Some Wheat Cultivars. International Journal of Agriculture and Crop Science, 4, 1110-1118.

[21] Lalelou, F.S. and Fateh, M. (2014) Effects of Water Deficit Stress and Nitrogen Fertilizer on Wheat Varieties. International Journal of Bioscience, 4, 183-189.

[22] Zodape, S.T., Gupta, A., Bhandari, S.C., Rawat, U.S., Chaudhry, D.R., Eswaran, K. and Chikara, J. (2011) Foliar Application of Seaweed Sap as Biostimulant for Enhancement of Yield and Quality of Tomato (Lycopersicon esculentum Mill.). Journal of Scientific and Industrial Research, 70, 215-219.

[23] Fageria N.K., Filhoa, M.P.B., Moreirab, A. and Guimaresa, M. (2009) Foliar Fertilization of Crop Plants. Journal of Plant Nutrition, 32, 1044-1064. http://dx.doi.org/10.1080/01904160902872826

[24] Abbasi, F.F., Baloch, M.A., Hassan, Z., Wagan, K.H., Shah, A.N. and Rajpar, I. (2010) Growth and Yield of Okra under Foliar Application of Some New Multi-Nutrient Fertilizer Products. Pakistan Journal of Agriculture, Agricultural Engineering Veterinary Sciences, 26, 11-18.

[25] Daubresse, M.C., Vedele, D.F., Dechorgnat, J., Chardon, F., Gaufichon, L. and Suzuki, A. (2010) Nitrogen Uptake, Assimilation and Remobilization in Plants: Challenges for Sustainable and Productive Agriculture. Annals of Botany, 105, 1141-1157. http://dx.doi.org/10.1093/aob/mcq028

[26] Varga, B. and Svecnjak, Z. (2006) The Effect of Late-Season Urea Spraying on Grain Yield and Quality of Winter Wheat Cultivars under Low and High Basal Nitrogen Fertilization. Field Crop Research, 96, 125-132. http://dx.doi.org/10.1016/j.fcr.2005.06.001

[27] Nasim, W., Ahmad, A., Hammad, H.M., Chaudhary, H.J. and Munis, M.F.H. (2012) Effect of Nitrogen on Growth and Yield of Sunflower under Semi-Arid Conditions of Pakistan. Pakistan Journal of Botany, 44, 639-648.

[28] Toosi, A.F. and Azizi, M. (2014) Effect of Different Sources of Nitrogen Fertilizer on Yield and Yield Components of Sunflower (Helianthus annuus L.). Scientific Papers Series: A Agronomy, 18, 364-366. 
[29] Hassan, S.W., Oad, F.C., Tunio, S., Gandahi, A.W., Siddiqui, M.H., Oad, S.M. and Jagirani, A.W. (2010) Effect of N Application and N Splitting Strategy on Maize N Uptake, Biomass Production and Physio-Agronomic Characteristics. Sarhad Journal of Agriculture, 26, 551-558.

[30] Malhi, S.S., Schoenau, J.J. and Grant, C.A. (2005) A Review of Sulfur Fertilizer Management for Optimum Yield and Quality of Canola in the Canadian Great Plains. Canadian Journal of Plant Sciences, 85, 297-307. http://dx.doi.org/10.4141/P04-140

[31] Eriksen, J. and Mortensen, J.V. (2002) Effects of Timing of Sulfur Application on Yield, S-Uptake and Quality of Barley. Plant and Soil, 242, 283-289. http://dx.doi.org/10.1023/A:1016224209654

[32] Malhi, S.S., Gan, Y. and Raney, J.P. (2007) Yield Seed Quality and Sulfur Uptake of Brassica Oilseed Crops in Response to Sulfur Fertilization. Agronomy Journal, 99, 570-577. http://dx.doi.org/10.2134/agronj2006.0269 